ks. Jan Dziedzic ${ }^{1}$

Uniwersytet Papieski Jana Pawła II w Krakowie

\title{
Kościół wobec zagrożeń związanych z wykluczeniem przez starość
}

Papież Franciszek w adhortacji apostolskiej Evangelii gaudium przypomniał, że jako chrześcijanie ,jesteśmy powołani do troski o najbardziej kruchych mieszkańców ziemi”" Niewątpliwie do tej grupy osób należy zaliczyć seniorów. Ludzie starsi ze względu na swój wiek, problemy zdrowotne, inwalidztwo mogą być narażeni na niezrozumienie, a nawet na społeczne wykluczenie. Wynika to z faktu, że ich stan ludzkiej kondycji kontrastuje z eksponowaną przez nowoczesne społeczeństwa siłą fizyczną, kreatywnością, pięknem i młodością. Brak zrozumienia dla ludzi starszych może wynikać również z kryzysu rodziny czy z zaniku relacji międzyosobowych spowodowanych anonimowością, zwłaszcza w dużych aglomeracjach ${ }^{3}$.

1 Jan Dziedzic - ks. dr hab., prof. UPJPII, kierownik Katedry Psychologii Pastoralnej na Wydziale Teologicznym Uniwersytetu Papieskiego Jana Pawła II w Krakowie. Prodziekan Wydziału Teologicznego UPJPII. Koordynator współpracy naukowej z Wydziałem Teologii Katolickiej Uniwersytetu Ruhry w Bochum. Kierownik Uniwersytetu Trzeciego Wieku przy UPJPII. Skupia się na badaniach naukowych z zakresu psychologii pastoralnej i tanatologii.

2 Franciszek, adhort. apost. Evangelii gaudium, 209.

3 J. Dziedzic, Nauczanie Jana Pawła II o szacunku dla osób wykluczonych przez starość, w: De revolutionibus orbium populorum Ioannis Pauli II. Papież wobec wykluczenia społecznego, red. K. Pilarczyk, Warszawa 2015, s. 501. 
Kościół dostrzega współczesne zagrożenia związane z marginalizacją osób starszych. Staje w obronie seniorów. Podkreśla, że każde życie ludzkie, nawet to najsłabsze, jest cenne i domaga się szacunku. Czwarte przykazanie dekalogu: „Czcij ojca i matkę swoją” zobowiązuje do poważania i respektu dla osób starszych. Ludziom w podeszłym wieku należy także zapewnić godziwe warunki egzystencji, a jeżeli jest to możliwe, trzeba ich włączyć w aktywne życie we wspólnocie. Osoby trzeciego wieku nie powinny wycofywać się z życia społecznego. Mogą dalej służyć swoimi kompetencjami zawodowymi i doświadczeniem życiowym.

W niniejszym opracowaniu zostanie przedstawiona problematyka zagrożeń związanych z wykluczeniem przez starość. Podjęte zagadnienie zostanie omówione w czterech punktach, z uwzględnieniem stanowiska Kościoła: 1) Zjawisko wykluczenia osób starszych, 2) Przeciwdziałanie marginalizacji ludzi w podeszłym wieku, 3) Zapobieganie samowykluczeniu w wieku senioralnym, 4) Włączenie seniorów do aktywności społecznej.

\section{Zjawisko wykluczenia osób starszych}

Każde społeczeństwo obok ludzi młodych posiada osoby starsze. Wobec seniorów można zająć postawę akceptacji albo dezaprobaty. Obie te postawy spotykamy zarówno w przeszłości jak i teraźniejszości. Współczesny deficyt demograficzny i wzrastająca liczba seniorów stają się dzisiaj wyzwaniem do budowania społeczeństwa akceptacji i szacunku dla ludzi starszych.

\subsection{Postawy wobec starości}

Starość to naturalna faza życia, następująca po młodości i dojrzałości, wieńcząca dynamiczny proces starzenia się. Z punktu widzenia

4 Por. E. Trafiałek, Starość, w: Encyklopedia pedagogiczna XXI wieku, t. 5, red. T. Pilch, Warszawa 2005, s. 945; O. Czerniawska, Wymiar czasu a przeżywanie starości, „Ethos” 3 (1999), s. 76-83. 
gerontologii ze starzeniem się związane są naturalne, nieodwracalne, nasilające się zmiany metabolizmu i właściwości fizykochemicznych komórek, prowadzące do upośledzenia samoregulacji i regeneracji organizmu oraz zmian morfologicznych i czynnościowych jego tkanek i narządów ${ }^{5}$.

Hipokrates twierdził, że przyczyną starzenia się organizmu jest utrata ciepła i wilgoci, gdyż w miarę upływu lat ciało staje się coraz bardziej zimne i suche $e^{6}$. U schyłku starożytności św. Augustyn zauważył, że już w chwili urodzenia w naszym ciele rozpoczyna się ciągły proces przemiany, który prowadzi do śmierci ${ }^{7}$. W myśli współczesnej Martin Heidegger określał człowieka jako „byt ku śmierci” (Sein zum Tode) ${ }^{8}$.

Biorąc pod uwagę podejście do osób starszych, trzeba zaznaczyć, że w starożytności człowiek stary był szanowany we wszystkich państwach o złożonym ustroju politycznym. W Kodeksie Hammurabiego wielokrotnie wspomina się o siwowłosych. U Persów królewskimi sędziami byli starcy, pełniący swój urząd aż do śmierci. W okresie koczowniczym Hebrajczycy uważali starców za naturalnych przywódców grupy. Szczególnym szacunkiem obdarzali starców Spartanie. „Ich młodzież, spotykając się ze starszymi, ustępuje im z drogi i usuwa się na bok, a kiedy nadchodzą, powstaje z siedzeń" .

Platon podkreśla, że starsi powinni rządzić, a młodzi słuchaćc ${ }^{10}$. Arystoteles, choć miał odrębną opinię na temat starości niż Platon, domagał się od młodych szacunku do ludzi w podeszłym wieku: „dla każdego starca żywić trzeba cześć odpowiednią jego wiekowi, wstawać na jego s. 949

A. A. Zych, Starość - starzenie się, w: Encyklopedia pedagogiczna XXI wieku, t. 5, dz. cyt.,

6 Por. H. Majkrzak, Starość człowieka jako problem filozoficzny wmyśli klasycznej, „Człowiek w Kulturze" 14 (2002), s. 200, https://docplayer.pl/10986261-Starosc-czlowieka-jako-problem-filozoficzny-w-mysli-klasycznej.html (18.07.2018).

7 Por. H. Majkrzak, Starość człowieka jako problem filozoficzny w myśli klasycznej, dz. cyt., s. 200 .

8 Por. H. Majkrzak, Starość człowieka jako problem filozoficzny w myśli klasycznej, dz. cyt., s. 200.

Por. H. Majkrzak, Starość człowieka jako problem filozoficzny w myśli klasycznej, dz. cyt., s. 203.

10 Platon, Prawa, III, 690, tłum. M. Maykowska, Warszawa 1960, s. 114. 
powitanie, wyznaczać mu najlepsze miejsce przy stole”"11. Powołujący się na Arystotelesa, Cyceron mówił, że „starzec przypomina sternika spokojnie stojącego przy sterze, podczas gdy inni biegają po pokładzie. W ten sposób robi on to, co jest ważniejsze i lepsze"12.

Szacunku wobec starości uczy Biblia. Stary Testament przenika przekonanie, iż długie życie jest darem Bożym (Ps 21, 5), którego Bóg udziela tym, którzy żyją zgodnie z Jego wolą (Job 36, 11; Prz 3, 2; 16 31) ) $^{13}$. Kiedy w starości człowiek musi podpierać się laską (Zach 8, 4); ma osłabiony wzrok (Rdz 27, 1; 48, 10; Sm 3, 2; 1 Kri 14, 4), Jahwe nie jest obojętny i zapewnia: „Aż do waszej starości ja będę ten sam i aż do siwizny ja was podtrzymam" (Iz 46, 4) $)^{14}$.

Ludzie starzy zasługują na szczególny szacunek. W księdze kapłańskiej czytamy: „Przed siwizną staniesz, będziesz szanował oblicze starca, W ten sposób okażesz bojaźń Bożą. Ja jestem Jahwe" (Kpł 19, 32). Na respekt zasługują przede wszystkim starzy rodzice. Zapewnia go IV przykazanie dekalogu: „Czcij ojca i matkę twoją, abyś długo żył na ziemi, którą twój Bóg Jahwe da tobie" (Wj 20, 12; por. Pwt 5, 16) ${ }^{15}$.

Nowy Testament podkreśla również to zobowiązanie. Jezus przypisuje przykazaniu czczenia rodziców tak wielką rangę, że radykalnie potępia zgodę rabinów na to, aby to, co miało być wsparciem dla rodziców, składano jako dar ofiarny w świątyni (Mt 15, 5n). Z nakazem szacunku ludzi starych spotykamy się w 1 Tm: „Starszego wiekiem nie strofuj, lecz nakłaniaj prośbą jak ojca [...], starsze kobiety jak matki [...]. Miej we czci te wdowy, które są rzeczywistymi wdowami” (5,1-3). W Kościele,

11 Arystoteles, Ethica Nicomachea IX 1, 1165a 28-30, tłum. D. Gromska: Arystoteles, Etyka Nikomachejska, Warszawa 1956 (Biblioteka Klasyków Filozofii, 25), s. 327, za: R. Majeran, Arystoteles o starości, „Vox Patrum” 31 (2011) 56, s. 106-107.

12 H. Majkrzak, Starość człowieka jako problem filozoficzny w myśli klasycznej, „Człowiek w Kulturze" 14 (2002), s. 208.

13 Por. J. Kudasiewicz, Sens starości w świetle Pisma Świętego, w: Ludzie chorzy i starsi w Kościele, red. B. Dąbrowski, Warszawa 1981, s. 91-101.

14 Por. K. Romaniuk, Lata podeszłe i starość według Biblii, Warszawa 1993, s. 11-22.

15 Por. Jan Paweł II, List do moich braci i sióstr - ludzi w podeszłym wieku, Watykan, 1 października 1999, nr 11. 
podobnie jak w rodzinie, ludzie starsi winni być otaczani miłością i szacunkiem, jakie należą się ojcu i matce ${ }^{16}$.

W kontekst biblijny wpisuje się nauczanie papieży. Za przykład dla seniorów papież Franciszek dał świętych Joachima i Annę, rodziców Maryi i dziadków Pana Jezusa, którzy wierzyli w przyszłe pokolenia i przekazali im swą mądrość. Pogodzili się w pokorze z faktem, że nie są ani początkiem, ani końcem historii, lecz jedynie ogniwem w długim łańcuchu dziejów ${ }^{17}$.

Według Jana Pawła II „wejście w tak zwany trzeci wiek należy uznać za przywilej nie tylko z tego powodu, że nie wszyscy mają szczęście przekroczyć ten próg, ale także dlatego, że jest to okres, w którym można lepiej przemyśleć i ocenić przeszłość, głębiej poznać i przeżyć tajemnicę paschalną, stać się w Kościele wzorem dla całego Ludu Bożego"18. Starość daje również możliwość stopniowego odrywania się od świata, pogłębiania relacji z Bogiem i przygotowania się do życia po drugiej stronie.

\subsection{Proces starzenia się ludności a wykluczanie}

Postępujący proces starzenia się ludności, zwłaszcza w Europie, jest istotnym czynnikiem determinującym zarówno rozwój społeczny, jak i gospodarczy. Jedną z miar określających zaawansowanie procesu starzenia się ludności jest udział ludności w wieku 65 lat i więcej w ogólnej populacji, czyli współczynnik starości.

Najstarszym demograficznie kontynentem jest Europa. Przyjmuje się, że większość krajów Unii Europejskiej to kraje zawansowane w procesie starzenia się ludności. W Polsce osoby w starszym wieku (65+) stanowią ponad 15 proc. ogólnej populacji, podczas gdy średnia dla całej UE wynosi prawie 19 proc., w tym wśród obywateli UE - prawie 20 proc. W 2014 roku mieszkaniec Polski miał przeciętnie 39,2 lat, a statystyczny mieszkaniec

16 Por. J. Kudasiewicz, Sens starości w świetle Pisma Świętego, w: Ludzie chorzy i starsi w Kościele, red. B. Dąbrowski, Warszawa 1981, s. 94.

17 Franciszek, Bronić się przed objawami psychicznej starości. Homilia z dnia 26 lipca 2013 http://teologia.pl/franciszek/franciszek_starosc_jak_wino.htm (15.07.2018).

18 Jan Paweł II, adhort. apost. Christifideles laici, 48. 
Unii Europejskiej był starszy o 3 lata. Dla całej społeczności UE pokolenie dziadków jest o jedną piątą liczniejsze niż pokolenie wnuków ${ }^{19}$.

Przewidywane zmiany w strukturze ludności spowodują podwyższenie przeciętnego wieku ludności wszystkich krajów UE. Potwierdzeniem tego będzie wzrost mediany wieku -w Polsce do prawie 50 lat w 2050 roku (z obecnych niespełna 40 lat) - i będzie to najwyższy po Słowacji prognozowany wzrost tego parametru. Mediana wieku dla całej UE wyniesie w 2050 roku nieco ponad 46 lat (wobec obecnych ok. 42 lat) ${ }^{20}$.

Zwiększy się także współczynnik starości (odsetek osób w wieku 65 i więcej lat) i dla całej Unii Europejskiej wyniesie nieco ponad 28 proc. W Polsce współczynnik starości zwiększy się prawie dwukrotnie i wyniesie ponad 30 proc. Ten kierunek zmian w strukturze ludności według wieku spowoduje zatem wzrost obciążenia demograficznego, rozumianego jako relacja liczby ludności w wieku 65 lat i więcej do liczby ludności w wieku produkcyjnym (15-64 lata) ${ }^{21}$.

Problem starości demograficznej nie jest nowy. Został on już zauważony w 1999 roku przez ONZ. Wtedy to z inicjatywy tej organizacji rok 1999 został ogłoszony Światowym Rokiem Ludzi Starszych. W inicjatywę ONZ włączył się Kościół, co zaowocowało wydaniem dokumentu Papieskiej Rady ds. Świeckich Godność i posłannictwo ludzi starszych w Kościele i w świecie (1998), oraz listu Jana Pawła II Do moich braci i sióstr - ludzi w podeszłym wieku (1999).

W swoim przemówieniu do uczestników konferencji Jan Paweł II podkreślił, że po raz pierwszy w dziejach człowieka społeczeństwo stanie w obliczu głębokich przemian w strukturze ludności i będzie zmuszone do modyfikacji swoich strategii opieki społecznej, czego skutki odczuwalne będą na wszystkich płaszczyznach. W opinii papieża

19 Por. J. Stańczak, D. Szałtys, J. Witkowski, Potencjał ludnościowy Unii Europejskiej, w: Ekonomiczna pozycja Europy w świecie, red. J. Kleer, K. Prandecki, Warszawa 2016, s. 17-20, http://www.prognozy.pan.pl/index.php/wydawnictwa/37-ksiazki-dotyczce-polski/134-ekonomiczna-pozycja-europy-w-swiecie (15.07.2018).

20 Por. J. Stańczak, D. Szałtys, J. Witkowski, Potencjał ludnościowy Unii Europejskiej, w: Ekonomiczna pozycja Europy w świecie, dz. cyt., s. 21-22.

${ }_{21}$ Por. J. Stańczak, D. Szałtys, J. Witkowski, Potencjał ludnościowy Unii Europejskiej, dz. cyt., s. 23. 
konieczne jest stworzenie nowych koncepcji społeczeństwa, przemyślenie na nowo jego struktury ekonomicznej i wzajemnych relacji między pokoleniami ${ }^{22}$.

W opinii papieża „, miarę jak wzrastać będzie średnia długość życia, a w konsekwencji także liczba ludzi starych, coraz bardziej konieczne będzie krzewienie kultury, która akceptuje i ceni starość, a nie spycha jej na margines społeczeństwa”"23. Stwarza to konieczność zwrócenia szczególniejszej uwagi na seniorów, aby pomóc im realizować w sposób pełny swe możliwości, służąc całej wspólnocie ${ }^{24}$.

Z punktu widzenie wiary ludzie starsi są darem. Benedykt XVI w czasie swojego pontyfikatu mówit: „Kiedy postęp w medycynie i inne czynniki prowadzą do przedłużenia życia ludzkiego, ważne jest uznanie obecności coraz większej liczby osób starszych za błogosławieństwo dla społeczeństwa"25.

Wzrost ludzi starszych w dzisiejszym świecie jest swoistym znakiem czasów. Właściwe odczytanie tego znaku może pomóc współczesnemu człowiekowi w odnalezieniu sensu życia, który wykracza poza przygodne oceny lansowane przez rynek, państwo i rozpowszechnioną mentalność ${ }^{26}$.

\subsection{Tendencje do wykluczania osób starszych}

$\mathrm{Na}$ kartach historii napotykamy w wielu miejscach na negatywne stereotypy dotyczące starości zawarte w komediach i satyrach greckich

22 Por. Jan Paweł II, o szacunku dla ludzi w podeszłym wieku. Przemówienie Ojca Świętego do uczestników konferencji zorganizowanej przez Papieską Radę ds. Duszpasterstwa Służby Zdrowia, Watykan 31.10.1999, „L’Osservatore Romano” wyd. pol. 3 (1999), s. 18-19, nr 4.

${ }_{23}$ Jan Paweł II, List Do moich braci i sióstr - ludzi w podeszłym wieku, dz. cyt., nr 13.

24 Jan Paweł II, Bo tu jest twoje życie i długie trwanie twego pobytu na ziemi (Pwt 30, 20). Orędzie Ojca Świętego Jana Pawła II na Wielki Post 2005 roku, Watykan, 8 września 2004, nr 1.

25 Benedykt XVI, Przemówienie w Domu dla osób starszych, 18 września 2010, https://www. deon.pl/religia/kosciol-i-swiat/z-zycia-kosciola/art,3092,benedykt-xvi-w-domu-dla-osob-starszych.htlm (18.06.2018).

${ }_{26}$ Por. Papieska Rada ds. Świeckich, Godność i posłannictwo ludzi starszych $w$ Kościele i w świecie, w: W trosce o życie. Wybrane dokumenty Stolicy Apostolskiej, t. 2, red. J. Brusiło, Tarnów 2012, nr 1. s. 499. 
i rzymskich. Pojawiają się też czcigodni starcy, święci i władcy ${ }^{27}$. Historia zna wiele przykładów dyskryminacji ludzi starych ${ }^{28}$. Szczególnie u ludów wędrownych mamy do czynienia z fenomenem porzucania ludzi starych, niedołężnych czy ciężko chorych. I tak np. wędrowni Eskimosi swoich starych i niedołężnych bliskich zaopatrywali w odrobinę prowiantu i ogień, pozostawiając ich na pewną śmierć29 ${ }^{29}$ Starcy i nieuleczalnie chorzy w ludach eskimoskich mieli także zwyczaj prosić swoje dzieci o zamurowanie ich $\mathrm{w}$ igloo ${ }^{30}$.

W Nowej Kaledonii ze względów ekonomicznych i z powodu litoś c i porzucano starców na pewną śmierć. Kafarowie eliminowali swoich starców przez śmierć głodową. Buszmeni rzucali ich dzikim zwierzętom na pożarcie. Karenowie z Birmy dotknięci bolesną chorobą wybierali śmierć przez powieszenie. Niedołężni z plemienia Payagua żądali, by zakopać ich żywcem w grobie. Hiperborejowie, nie chcąc znosić mąk starości, rzucali się z wysokiej skały do morza ${ }^{31}$.

Nad brzegami Gangesu uśmiercanie miało charakter rytualny. Przyprowadzanym tam starcom wypełniano usta świętym mułem i wrzucano ich do wody. Na wyspie Kos ludzi będących ciężarem społecznym zwoływano na festyn, podczas którego podawano im napój z trucizną. Była to praktyka legalna, ustanowiona przez senat ${ }^{32}$. U wielu ludów dobrowolne uprzedzanie śmierci było zwyczajem.

Marginalizacja osób starszych miała miejsce w starożytności i przetrwała do czasów współczesnych. Mimo rozwoju cywilizacyjnego i religijnego tendencje dyskryminujące seniorów mają miejsce do dziś i widoczne są w dzisiejszej kulturze. Zwraca na to uwagę papież Franciszek w adhortacji Evangelii gaudium: „Wykluczenie ubogich oraz

${ }_{27}$ Por. O. Czerniawska, Starość wczoraj, dziś i jutro, http://kutw.kk.jgora.pl/witryna 3/ starosc.htm (12.07.2018).

28 Por. J. Dziedzic, Spór o eutanazję, Kraków 2005, s. 14-15.

29 Por. U. Eibach, Sterbehilfe-Ttong auf verlangen? Eine theologisch-ethische Stellungnahme zur Frage der Euthanasie, Bonn 1987.

${ }^{30}$ Por. W. Gwóźdź, Eutanazja jako problem moralny, „Studia Sandomierskie” 2 (1981), S. 458.

31 Por. W. Gwóźdź, Eutanazja jako problem moralny, dz. cyt., s. 458-459.

32 Por. J. Bréhant, Thanatos: Chory i lekarz w obliczu śmierci, przeł. U. Sudolska, Warszawa 1993, s. 140 . 
trudności w otrzymaniu niezbędnej opieki i leczenia jest sytuacją, która niestety istnieje także i dziś. Dokonano wielkich postępów w medycynie i pomocy społecznej, ale rozprzestrzeniła się także kultura odrzucenia, będąca następstwem kryzysu antropologicznego, który w centrum nie stawia już człowieka, ale konsumpcję i interesy ekonomiczne" (Evangelii gaudium, 52-53). Do tych odrzuconych w naszych czasach papież zaliczył m.in. ludzi starszych ${ }^{33}$.

Zdaniem Benedykta XVI ludzie starsi, a wśród nich wielu dziadków, znaleźli się w czymś na kształt „strefy parkingowej”: niektórzy widzą, że są ciężarem dla rodziny, i wolą żyć sami lub w domach spokojnej starości, ze wszystkimi konsekwencjami, jakie te decyzje za sobą pociągają ${ }^{34}$.

W świecie, w którym panuje kult wydajności, pojawia się pokusa traktowania osób starszych jako bezużytecznych ciężar ${ }^{35}$. Istnieje niebezpieczeństwo, że współczesna kultura, która ceni rachunek ekonomiczny, efektywność, dobrobyt, piękno i siłę, może dostrzegać w osobach starszych niewygodne obciążenie i odsuwać je na margines życia rodzinnego i społecznego ${ }^{36}$.

Coraz bardziej rozwija się „kultura śmierci”, która jest zagrożeniem również dla trzeciego wieku. Dochodzi wręcz do tego, że proponuje się z coraz większym naciskiem eutanazję jako sposób rozwiązania niektórych trudnych sytuacji ${ }^{37}$. Niestety w ostatnich latach sama idea

33 Por. Franciszek, Starsi to ofiary kultury odrzucenia, Przemówienie w Małym Domu Opatrzności Bożej, Turyn, 21 czerwca 2015, https://papiez.wiara.pl/doc/2555377.Starsi-toofiary-kultury-odrzucenia/2 (18.07.2018).

${ }_{34}$ Por. Benedykt XVI, Dziadkowie sa cennym skarbem każdej rodziny. Przemówienie do uczestników XVIII Zgromadzenia Plenarnego Papieskiej Rady ds. Rodziny, 5 kwietnia 2008, s. 1, http://www.opoka.org.pl/biblioteka/W/WP/benedykt_xvi/przemowienia/dziadkowie_05042008.html (15.07.2018).

35 Por. Jan Paweł II, Cenna rola starszych w Kościele. Przemówienie z 7.09.1994, „L’ Osservatore Romano" wyd. pol. 11 (1994), s. 38, nr 1.

36 Por. Jan Paweł II, Środki Przekazu Społecznego i problemy ludzi starszych, Orędzie na XVI Światowy Dzień Środków Przekazu Społecznego, 10.05.1982, Watykan 1982, w: Jan Paweł II. O cierpieniu. Wypowiedzi Ojca Świętego do chorych i pracowników służby zdrowia (1982-1984), Niepokalanów 1988, t. 2, s. 27, nr 4.

37 Por. Benedykt XVI, Dziadkowie są cennym skarbem każdej rodziny, dz. cyt., s. 1. 
eutanazji przestała budzić w wielu ludziach uczucie zgrozy ${ }^{38}$, czego dowodem jest legalizacja tego procederu, choćby w Holandii, Belgii czy Szwajcarii.

Jan Paweł II podkreśla: „Nie można oceniać życia i jego spraw jedynie na podstawie kryterium ekonomicznego czy kryterium skuteczności. W ten sposób dehumanizują się stosunki między ludźmi, zubaża się rodzina i społeczeństwo" ${ }^{39}$. Troszcząc się o godność seniorów, trzeba zawsze mocno reagować na to, co odczłowiecza społeczeństwo ${ }^{40}$. Musimy rozwijać „przeciwciała” wobec takiego sposobu postrzegania osób starszych czy niepełnosprawnych, jakby ich egzystencja nie była już godna dalszego życia ${ }^{41}$ - dodaje papież Franciszek.

\section{Przeciwdziałanie marginalizacji ludzi w podeszłym wieku}

W swoim nauczaniu Kościół wzywa do szacunku wobec osób starszych i przestrzega przed ich marginalizacją. Czyni to, ukazując absolutną wartość osoby ludzkiej w każdej bez wyjątku fazie życia. Respekt wobec godności człowieka winien znaleźć potwierdzenie w działaniach społecznych i duszpasterskich. O pełne włączenie seniorów do wspólnoty powinny zabiegać zarówno państwo, jak i Kościół.

\subsection{Respekt wobec godności osoby ludzkiej}

Kościół zawsze głosił transcendentną wartość osoby, której godność pozostaje nienaruszona mimo cierpienia, choroby i starości ${ }^{42}$. Tak jak Jezus troszczył się o chorych i cierpiących, tak Kościół zabiega o godność osób

38 Por. Jan Paweł II, List do moich braci i sióstr - ludzi w podeszłym wieku, dz. cyt., nr 9.

39 Jan Paweł II, Spotkanie z osobami Trzeciego Wieku $w$ Walencji 8.11.1982, Jan Paweł II, O cierpieniu. Wypowiedzi Ojca Świętego do chorych i pracowników służby zdrowia (1982-1984), Niepokalanów 1988, t. 2, s. 65.

40 Por. Benedykt XVI, Dziadkowie są cennym skarbem każdej rodziny, dz. cyt., s. 1.

41 Franciszek, Starsi to ofiary kultury odrzucenia, dz. cyt.

42 Por. Jan Paweł II, Nadzieja nadaje cierpieniu nowy sens. Orędzie na VI Światowy Dzień Chorego 11.02.1998, „L'Osservatore Romano” wyd. pol. 10 (1997), s. 4-6, nr 9. 
starszych i należne im uznanie ${ }^{43}$. Starszy człowiek nie może być postrzegany tylko przez pryzmat tego, co teraz daje i wnosi, ale według tego, co dał. Nie może być oceniany na podstawie tego, co robi, ale w oparciu przede wszystkim o to, kim jest ${ }^{44}$. „Cierpienie, starość, stan nieświadomości oraz bliskiej śmierci nie pomniejszają niezbywalnej godności osoby, stworzonej na obraz Boży"45. Ewangelia wielokrotnie wzywa do otoczenia życia opieką i szacunkiem, zwłaszcza życia naznaczonego przez chorobę i starośćc ${ }^{46}$.

Na ludzi starszych trzeba patrzeć przede wszystkim w świetle ich godności ludzkiej, która „nie zanika w miarę upływu lat i pogarszania się stanu psychicznego i fizycznego" ${ }^{47}$. Każdy człowiek jest stworzony z miłości, uczyniony na Boży obraz i podobieństwo (por. Rdz 1, 26). To stwierdzenie ukazuje nam ogromną godność każdej osoby ludzkiej, która „nie jest tylko czymś, ale kimś". Osoba jest podmiotem, którego nigdy nie można redukować do kategorii przedmiotu ${ }^{48}$.

Życie ludzkie pozostaje cenne w każdym wieku i w każdym stanie ${ }^{49}$. Jan Paweł II sprzeciwia się wszelkim praktykom skracania życia. Życie bowiem jest darem Bożym i jego ochrona należy do każdego $\mathrm{z}$ nas ${ }^{50}$. Szacunek, jaki winniśmy okazywać starszym, wyklucza wszelkie praktyki skracania życia. Życie człowieka jest bowiem cennym darem, który należy kochać, i którego trzeba bronić w każdej fazie. „Eutanazja to zamach na życie, którego nie może uprawomocnić żadna ludzka władza, jako że życie ludzkie jest dobrem nienaruszalnym" ${ }^{\text {"11. }}$.

43 Por. Jan Paweł II, Spotkanie z osobami starszymi w diecezji rzymskiej 20.12.1982, w: Jan Paweł II, O cierpieniu. Wypowiedzi Ojca Świętego do chorych i pracowników służby zdrowia (19821984), t. 2, dz. cyt., s. 75.

${ }_{44}$ Por. Jan Paweł II, Spotkanie z osobami starszymi w diecezji rzymskiej 20.12.1982, dz. cyt.

45 Jan Paweł II, Towarzyszyć choremu aż do końca. Przemówienie do uczestników konferencji Papieskiej Rady ds. Duszpasterstwa Służby Zdrowia 12 listopada 2004, nr 3.

46 Por. Paweł VI, enc. Humanae Vitae, 44.

47 Jan Paweł II, List papieski do uczestników II Światowego Zgromadzenia poświęconego problemom starzenia się ludności, Watykan 3 kwietnia 2002, s. 9, https://opoka.org.pl/biblioteka/W/ WP/jan_pawel_ii/listy/ludzie_starsi_03042002.html (20.05.2018)

48 Por. Franciszek, enc. Laudato si', 81.

49 Por. Jan Paweł II, O szacunku dla ludzi w podeszłym wieku..., dz. cyt., nr 2.

50 Por. Jan Paweł II, O szacunku dla ludzi w podesztym wieku..., dz. cyt., nr 8.

51 Por. Jan Paweł II, O szacunku dla ludzi w podeszłym wieku..., dz. cyt., nr 8; por. J. Dziedzic, Spór o eutanazję, dz. cyt., s. 53-56. 
Nie wolno również zapominać, że „przykazanie Nie zabijaj domaga się poszanowania i promowania życia od początku po naturalny kres. To przykazanie obowiązuje także w obliczu choroby i wówczas, kiedy spadek sił ogranicza zdolność człowieka do autonomii" ${ }^{52}$. Panem każdej ludzkiej istoty, każdego ludzkiego życia jest Bóg, a nie człowiek ${ }^{53}$. Życie to dar Boży, którego ochrona jest zadaniem wszystkich.

Do rezygnacji z życia nie upoważnia człowieka w podeszłym wieku nawet najtrudniejsza sytuacja egzystencjalna. W Evangelium vitae czytamy: „Sprawiedliwy nie prosi o uwolnienie od starości i od jej ciężaru, przeciwnie, modli się słowami: «Ty bowiem, mój Boże, jesteś moją nadzieją, Panie, ufności moja od moich lat młodych! [...] Lecz i w starości, w wieku sędziwym nie opuszczaj mnie, Boże, gdy moc Twego ramienia głosić będę, całemu przyszłemu pokoleniu - Twą potęgę»" (Ps 71 [70], 5.18) $)^{54}$.

\subsection{Obowiązki społeczeństwa wobec seniorów}

Jeśli afirmacja godności człowieka starszego ma być wiarygodna i autentyczna, winna znajdować wyraz w działaniach politycznych zmierzających do sprawiedliwego podziału zasobów, tak aby wszyscy obywatele, w tym także ludzie starsi, mogli z nich korzystać ${ }^{55}$. Jest to istotne zwłaszcza teraz, kiedy wzrost liczby osób starszych, wynikający ze wzrostu przeciętnej długości życia i niżu demograficznego, prowadzi do przemian w strukturze ludności. Taka sytuacja wymusza modyfikację strategii opieki społecznej ${ }^{56}$.

Szerzej chodzi o taką politykę, która zakłada działania na rzecz praw ludzi starszych. Dotyczy to oświaty, kultury, pracy, organizacji czasu wolnego oraz ochrony pracy tych osób. Polityka społeczna winna objąć takie zagadnienia jak: ochrona zdrowia seniorów, zatrudnienie osób starszych, pomoc osobom obłożnie chorym, praca socjalna z osobami starszymi,

52 Jan Paweł II, Bo tu jest twoje życie i długie trwanie twego pobytu na ziemi (Pwt 30, 20)..., dz. cyt., nr 2.

53 Franciszek, adhort. apost. Gaudate et Exultate, 32.

${ }^{54}$ Jan Paweł II, Ludzie starsi w życiu społeczeństwa..., dz. cyt.

55 Jan Paweł II, Ludzie starsi w życiu społeczeństwa..., dz. cyt.

56 Por. Jan Paweł II, O szacunku dla ludzi w podeszłym wieku..., dz. cyt., nr 4. 
kształtowanie odpowiednich warunków mieszkaniowych, pomoc instytucjonalna oraz warunki materialne seniorów. W tym kontekście zwraca się uwagę na ubóstwo jako problem towarzyszący często starości ${ }^{57}$.

W szczególności powinny być podjęte działania polegające na rozbudowie infrastruktury socjalnej, kulturalnej, oświatowej i rekreacyjnej dostosowanej do potrzeb tej grupy wiekowej. Dotyczy to placówek służby zdrowia, domów różnorodnej opieki, klubów seniora. Należy również poszerzyć formy wsparcia dla rodziny i dla żyjących w niej osób starszych ${ }^{58}$. W większym stopniu trzeba też umożliwić podejmowanie pracy odpowiadającej możliwościom osób w podeszłym wieku. Niezbędne jest aktywizowanie osób starszych do działań samopomocowych, a także zapobieganiu ich izolowaniu się ${ }^{59}$. Ważne jest także wzmocnienie aktywności osób trzeciego wieku np., włączenie ich w aktywne życie społeczne.

Nie bez znaczenia jest także edukacja dla seniorów. Może się ona dokonywać choćby na uniwersytetach trzeciego wieku, które przez aktywizację osób starszych pomagają im zaadaptować się do zmian zachodzących we współczesnym świecie ${ }^{60}$.

Jan Paweł II, broniąc godności każdej osoby ludzkiej, przestrzegał przed wykluczaniem seniorów ze wspólnoty ${ }^{61}$. Mówił zdecydowanie: „Jeżeli społeczeństwo, kierując się jedynie kryterium konsumizmu i wydajności, dzieli ludzi na aktywnych i nieaktywnych i uważa tych drugich

57 Por. K. Wyrwicka, Osoby starsze w systemie pomocy społecznej, „Praca Socjalna” 2 (2003), S. 109.

58 Por. K. Wyrwicka, Osoby starsze w systemie pomocy społecznej, dz. cyt., s. 110.

59 Por. M. Dzięgielewska, Aktywność społeczna i edukacja w fazie starości, w: Podstawy gerontologii społecznej, red. B. Szatur-Jaworska, Warszawa 2006, s. 160-164; M. Dzięgielewska, Wolontariat ludzi starszych, w: Starzenie się a satysfakcja z życia, red. S. Steuden, M. Marczuk, Lublin 2006; s. 261-271.

60 Por. A. Grzanka-Tykwińska, M. Chudzińska, M. Podhorecka, K. Kędziora-Kornatowska, Uniwersytety Trzeciego Wieku wczoraj, dziś i jutro, „Gerontologia Polska” 4 (2015), s. 165.

${ }^{61}$ Por. J. Dziedzic, Kościót wobec starości. Perspektywa pastoralnoteologiczna, w: Starość. Problem czy szansa? Refleksja pastoralnoteologiczna, red. J. Dziedzic, Kraków 2015, s.47-49; J. Dziedzic, Nauczanie Jana Pawła II o szacunku dla osób wykluczonych przez starość, dz. cyt., s. $483-488$. 
za obywateli drugiej kategorii, pozostawiając ich własnej samotności, nie może nazywać się społeczeństwem naprawdę cywilizowanym"62.

W swoim nauczaniu społecznym Kościół często broni praw osób starszych. W liście skierowanym do II Światowego Zgromadzenia poświęconego problemom starzenia się ludności Jan Paweł II pisze: „Nasza cywilizacja musi zapewnić ludziom starszym opiekę nacechowaną głębokim człowieczeństwem i przenikniętą prawdziwymi wartościami. Do realizacji tego celu w istotny sposób może się przyczynić rozwój medycyny paliatywnej, współpraca wolontariuszy, zaangażowanie rodzin - którym należy pomagać w wypełnianiu ich powinności - oraz humanizacja instytucji opieki socjalnej i ochrony zdrowia, które zajmują się ludźmi starszymi”63.

\subsection{Wsparcie Kościoła}

Oprócz czynników społecznych ważną rolę w twórczym przeżywaniu starości może odegrać Kościół ${ }^{64}$. Kościół zawsze, zarówno w ciągu dziejów, jak i obecnie, odznaczał się wrażliwością na potrzeby ludzi starszych. Troska Kościoła w tym względzie znalazła swój wyraz również w dokumentach wydawanych przez Stolicę Apostolską, sobór i różnego rodzaju konferencje międzynarodowe i partykularne. Generalnie z tematem starości możemy się spotkać wszędzie tam, gdzie jest mowa o poszanowaniu godności każdego człowieka ${ }^{65}$.

Jasno zaznaczył to Jan Paweł II w swoim orędziu na Wielki Post 2005, w którym napisał: „Troska o osoby starsze, zwłaszcza wtedy gdy przeżywają chwile trudne, winna leżeć na sercu wiernym, szczególnie we wspólnotach kościelnych". Problematykę starości papież podejmował wiele

62 Jan Paweł II, Poparcie roli osób starszych w rodzinie i społeczeństwie. Przemówienie do członków Krajowej Federacji Handlu i Turystyki, Watykan 29.04.1982, w: Nauczanie Papieskie, t. 5/1, Poznań 1993, s. 614, nr 4.

63 Jan Paweł II, Ludzie starsi w życiu społeczeństwa..., dz. cyt..

${ }^{64}$ Por. J. Dziedzic, Wsparcie osób starszych. Przeszkody $i$ szanse w poszukiwaniu godnej starości, w: Odnaleźć wykluczonych, red. J. Dziedzic, J. Klimek, Kraków 2014, s. 227-229; K. M. Marczewski, Z upływem lat oswajamy się z myślą o zmierzchu (Duszpasterstwo ludzi starszych), „Roczniki Naukowe Caritas” 10 (2006), s. 28-35.

${ }_{65}$ Por. W. Irek, Koniec czy poczatek? Szkice o godnym starzeniu sięi umieraniu, Wrocław 2009, S. 43. 
razy już wcześniej, choćby w adhortacji apostolskiej Familiaris consortio. W dokumencie tym mówił o szczególnych rodzajach duszpasterstwa w odniesieniu do różnych kategorii ludzi, wśród których wymienia „osoby starsze, nierzadko zmuszone do życia w samotności i bez wystarczających środków utrzymania" ${ }^{66}$. Podobnie soborowy dekret o apostolstwie świeckich wśród różnych rodzajów apostolstwa wymienia „zapewnienie starcom nie tylko niezbędnych środków do życia, ale także słusznego udziału w owocach postępu gospodarczego"67.

W dokumencie Papieskiej Rady ds. Świeckich Godność i posłannictwo ludzi starszych w Kościele i świecie Kościół wzywa do poszanowania godności i podstawowych praw ludzi starszych. Powołuje się przy tym na zasadę pomocniczości, by wszyscy obywatele mieli dostęp do dóbr niezbędnych dla zaspokojenia potrzeb życiowych ${ }^{68}$. W podobnym duchu przemawia Jana Paweł II w liście zaadresowanym do uczestników II Światowego Zgromadzenia poświęconego problemowi starzenia się ludności. Papież zauważa, że zjawisko starzenia się społeczeństw jest globalne. Dlatego wszystkie kraje muszą podjąć na nowo debatę nie tylko o strukturze ekonomicznej społeczeństw, ale także o samej koncepcji cyklu życia i relacji miedzypokoleniowej. Aby zapewnić starzejącemu się społeczeństwu przetrwanie, należy przede wszystkim kierować się zasadami moralnymi. Trzeba patrzeć na człowieka starszego przez prymat jego godności, która nie znika w miarę upływu lat ${ }^{69}$.

Kościół podejmuje także konkretną działalność na rzecz najstarszych członków społeczeństwa. W duszpasterstwie parafialnym troska o ludzi starszych może przybrać wiele form ${ }^{70}$. Może to być tworzenie kół biblijnych, kursów duchowości, czy grup modlitewnych. Inspiracją do organizowania ludzi starszych mogą być hasła typu „parafia - twój dom”, „nie jesteś sam”, ,jesteś nam potrzebny”. Wokół tych treści można tworzyć

66 Jan Paweł II, adhort. apost. Familiaris consortio, 19.

67 Sobór Watykański II, Dekret o apostolstwie świeckich, 20.

68 Por. Papieska Rada do Spraw Świeckich, Godność i posłannictwo ludzi starszych w Kościele i świecie, „Wrocławskie Wiadomości Kościelne” 3 (1999), s. 3.

69 Por. Jan Paweł II, Ludzie starsi w życiu społeczeństwa..., dz. cyt.

70 Por. W. Przygoda, Wezwania duszpasterskie wobec osób w podeszłym wieku, w: Starość. Problem czy szansa?..., dz. cyt., s. 77-116. 
różne grupy, które same znajdą motyw i scenariusz spotkań w parafii lub domach prywatnych. W domach parafialnych byłoby wskazane przeznaczyć salkę na kawiarenkę dla seniorów. Może ją obsługiwać młodzież z programem kulturalnym i edukacyjnym.

Ważne jest także zachęcanie ludzi w podeszłym wieku do uczestnictwa w kręgach rodzin Żywego Różańca, Apostolstwa Chorych czy w innych bractwach i stowarzyszeniach religijnych. Takie grupy przyparafialne ukażą chrześcijański sposób przeżywania upływającego życia i tym samym zaspokoją potrzebę przepojenia ludzkiej egzystencji wymiarem religijnym $^{71}$. W sytuacji choroby i cierpienia najlepszym wsparciem takich osób jest wizyta w domu lub w szpitalu z posługą sakramentu namaszczenia chorych i słowem pocieszenia ${ }^{72}$.

\section{Zapobieganie samowykluczeniu w wieku senioralnym}

W refleksji na problematyką wykluczenia osób starszych istotne jest pytanie o indywidualne podejście do swojej starości. Człowiek starszy może bowiem sam się wykluczyć ze społeczeństwa. W tym kontekście należy pamiętać, że „starość kształtuje się wraz z nami i styl naszej starości będzie zależał od tego, jak potrafimy odkryć jej sens i wartość, zarówno na płaszczyźnie czysto ludzkiej, jak i w świecie wiary ${ }^{73}$.

Do potrzeby rozwijania dobrych nawyków w młodości i kontynuowania ich w starości wzywa już prorok Syrach. Mówi on: „Synu, od młodości swej staraj się o naukę, a będziesz ją nabywał aż do siwizny" (Syr 6, 18). Starość jest więc tym czasem, w którym człowiek może najlepiej pojąć sens życia i zdobyć „mądrość serca" ${ }^{4}$. Aby zapobiec samowykluczeniu, trzeba dbać o aktywność fizyczną i psychiczną oraz o rozwój duchowy.

${ }_{71}$ Por. J. Leonowicz, Duszpasterstwo ludzi starych, w: Duszpasterstwo specjalistyczne, red. R. Kamiński, B. Drożdż, Lublin 1998, s. 50.

72 Por. A. Siemianowski, Starość w perspektywie ostatecznej, „Ethos” 3 (1999), s. 104-105.

73 Por. Papieska Rada ds. Świeckich, Godność i posłannictwo ludzi starszych w Kościele i w świecie, w: W trosce o życie..., dz. cyt., nr 1. s. 502.

74 Por. H. Sławiński, Przepowiadanie do ludzi w podeszłym wieku, „Analecta Cracoviensia” 48 (2016), s. 56. 


\subsection{Aktywność fizyczna i psychiczna}

Perspektywicznie na starość patrzył Hipokrates, wskazując, że tryb życia, ćwiczenia i treningi stosowane w wieku średnim zapewniają człowiekowi sprawność na starość. Podobne stwierdzenie można znaleźć prawie 600 lat później u znakomitego lekarza greckiego Galena z Pergamonu. Także Platon widział potrzebę pielęgnowania indywidualnego trybu życia w młodości i w średnim wieku. Podkreślał, że spotkanie ze starością oraz to, jak człowiek ją widzi i odbiera, zależy od wielu czynników. Mówił: „żeby przyjąć starość ze spokojem i mądrością, należy żyć porządnie w poprzednich etapach życia"75. Dzisiaj twierdzimy podobnie: aby człowiek mógł zażywać pomyślnej starości, jego życie powinno upływać na rzetelnym spełnianiu obowiązków. Jest to historyczny dowód na to, że geroprofilaktyka musi mieć miejsce już w dzieciństwie i młodości ${ }^{76}$.

Do czynników hamujących starzenie się zaliczamy: aktywność fizyczną i psychiczną, prawidłową dietę, odpowiedni tryb życia, wystrzeganie się nałogów, troskę o ekologię i poprawę warunków pracy. Istotny jest też wypoczynek. W konstytucji duszpasterskiej o Kościele w świecie współczesnym czytamy: „Niech wolny czas będzie należycie użyty dla odprężenia duchowego, wzmocnienia zdrowia psychicznego i fizycznego przez swobodne zajęcia i studia, przez podróże w obie strony, dzięki którym doskonali się umysł i ludzie wzbogacają się przez wzajemne poznanie" (KDK 61). Ruch, który oddziałuje na cały organizm człowieka, przyczynia się do poprawy samopoczucia i satysfakcji z życia. Aktywność fizyczna wpływa na poprawę koncentracji, zdyscyplinowanie wewnętrzne, systematyczność, obowiązkowość i wytrwałośćn ${ }^{77}$.

Kontakt z przyrodą pozytywnie wpływa na psychikę człowieka. Stwarza warunki do odprężenia, relaksu, wzbudza pozytywne stany emocjonalne. Szczególną rolę odgrywa związana z turystyką aktywność

75 Cyt. za: J. Rembowski, Psychologiczne problemy starzenia się człowieka, WarszawaPoznań 1984, s. 126.

76 Por. J. Rembowski, Psychologiczne problemy starzenia się człowieka, dz. cyt., s. 126.

77 Por. K. Zieliński, Edukacyjne walory sportu rekreacyjnego i wyczynowego. Perspektywa personalistyczna, w: Edukacja sportu, red. Z. Dziubiński, Warszawa 2004, s. 148. 
ruchowa. Wysiłek fizyczny w czystym ekologicznie środowisku przyrodniczym, związany z wydatkowaniem energii, zmęczeniem i procesami regeneracyjnymi, wpływa na proces samoodnowienia się organizmu, jak również na poprawę samopoczucia jednostki ${ }^{78}$. Brak aktywności fizycznej osłabia odporność immunologiczną organizmu, nasila rozwój chorób metabolicznych, chorób układu krążenia i obniża sprawność psychiczną. Natomiast wysiłek fizyczny obniża napięcie emocjonalne, redukuje lęk, gniew i depresję. Często po powrocie z wycieczki towarzyszy nam uczucie zadowolenia i satysfakcji ${ }^{79}$.

\subsection{Rozwój duchowy}

W podejściu do starzenia się należy pamiętać, że osobowość człowieka nigdy nie jest gotowa, ale ciągle się staje. Podkreśla to papież Franciszek, kiedy mówi, że starość jest powołaniem; nie jest to jeszcze czas, aby „wyciągnąć wiosła na pokład"80.

Historia podaje wiele przykładów ludzi, którzy mimo sędziwego wieku okazali się bardzo aktywni i twórczy. I tak Sofokles w 90. roku życia napisał Edypa, Tycjan w wieku 96 lat malował Pietę, Michał Anioł mając 82 lata pracował nad konstrukcją bazyliki św. Piotra, Verdi w wieku 80 lat skomponował komedie Falstaff, fizjolog Pawłow u szczytu sławy był w wieku 87 lat, a angielski matematyk Whitehead zajął się filozofią po sześćdziesiątce.

Istotnym elementem w formowaniu dojrzałych odniesień wobec starości jest utrwalanie przekonania, że starość nie jest stratą, ale szansą dalszego rozwoju ${ }^{81}$. Integralny rozwój polega na tym, aby zachować właściwe proporcję pomiędzy ludzkim „być” i „mieć”"2. Chociaż „mieć”

78 Por. R. Winiarski, J. Zdebski, Psychologia turystyki, Warszawa 2008, 107-108.

79 Por. R. Winiarski, J. Zdebski, Psychologia turystyki, dz. cyt., s. 107-108.

80 Franciszek, Potrzebujemy osób starszych, które się modla, Przemówienie z 11 marca 2015 https://papiez.wiara.pl/doc/2387276.Potrzebujemy-osob-starszych-ktore-sie-modla (15.07.2018).

${ }^{81}$ Por. K. Uzar, Wychowanie w perspektywie starości. Personalistyczne podstawy geragogiki, Lublin 2011, s. 100-101; J. Sztuka, Formacja do starości, „Ateneum Kapłańskie” 157 (2011) z. 1, S. $46-51$.

${ }^{82}$ Por. Jan Paweł II, enc. Sollicitudo rei socialis, 28. 
niejednokrotnie stanowi niezbędną bazę dla „być” to jednak, aby mówić o autentycznym rozwoju osoby, „być” osoby musi stanowić wartość nadrzędną wobec jej „mieć”83.

Aby wypracować w sobie postawę „bardziej być” niż „mieć”, należy kształtować w sobie nowe nawyki. Duchowość chrześcijańska proponuje tu rozwój wstrzemięźliwości, która jest związana z prostotą życia. Człowiek, nawet kiedy niewiele posiada, potrafi być wdzięczny za to, co ma, i nie doświadcza negatywnych emocji, w tym smutku powodowanego tym, że czegoś mu brakuje ${ }^{84}$. Wstrzemięźliwość pomaga także zredukować zmęczenie i niepokój, które są związane z postawą konsumpcyjną, polegającą na chęci posiadania ciągle więcej. Osoby wstrzemięźliwe charakteryzują się większą tolerancją na zaspokajanie potrzeb i pewną umiejętnością ich ograniczania ${ }^{85}$. Taka postawa ułatwia pokonywanie trudności życiowych, zwłaszcza kiedy problemy i cierpienia wystawiają na próbę odporność psychofizyczną człowieka $^{86}$.

Benedykt XVI zauważa, że „choć z upływem lat zmniejszają się nasze możliwości fizyczne, „to czas ten może się okazać jednym z najbardziej owocnych duchowo w naszym życiu"87. Dla człowieka wierzącego nie istnieje czas spoczynku w spełnianiu woli Bożej. Każdy człowiek jest wezwany do świętości ${ }^{88}$. Mimo upływu lat ludzie starsi winni czuć się bardziej niż kiedykolwiek wezwani na szczyty chrześcijańskiej świętości. Chrześcijanin nie może dopuścić, by apatia i zmęczenie hamowały jego duchowy postęp ${ }^{89}$. Motywacją do pracy nad ciągłym rozwojem winny

83 Por. M. Wyrostkiewicz, Ekologia ludzka. Osoba i jej środowisko z perspektywy teologicznomoralnej, Lublin 2007, s. 102; J. Dziedzic, Kościół wobec kwestii ekologicznej, w: Ekoturystyka, red. J. Dziedzic, P. Tirpak, Presov 2013, s. 45.

84 Franciszek, enc. Laudato si', 209 i 222.

85 Franciszek, enc. Laudato si', 223.

86 Jan Paweł II, List Do moich braci i sióstr - ludzi w podeszłym wieku, dz. cyt., 2.

87 Benedykt XVI, Przemówienie w Domu dla osób starszych, dz. cyt.

88 Por. Jan Paweł II, Spotkanie z uczestnikami pielgrzymki Federacji Organizacji Emerytów i Osób Starszych 21.05.1982, w: Jan Paweł II, O cierpieniu. Wypowiedzi Ojca Świętego do chorych i pracowników stużby zdrowia (1982-1984), t. 2, dz. cyt., s. 30.

${ }_{89}$ Por. Papieska Rada ds. Świeckich, Godność i posłannictwo ludzi starszych w Kościele i w świecie, w: W trosce o życie..., dz. cyt., s. 509, nr 4. 
być słowa Jezusa: „Bądźcie doskonali, jak doskonały jest Ojciec wasz niebieski” (Mt 5, 47) ${ }^{90}$.

Rozwój jest otwarty także na budowanie relacji z Bogiem. Wiara otwiera przed nami „nadzieję, która zawieść nie może” (por. Rz 5, 5), wskazując perspektywę zmartwychwstania na końcu czasów ${ }^{91}$. Duch ludzki - zauważa Jan Paweł II w liście do osób starszych - mimo że odczuwa skutki starzenia się ciała, jest stale otwarty ku wieczności ${ }^{92}$. W życiu należy dostrzec pewną całość. Każdy jego etap jest ważny ${ }^{93}$. Jednym z tych etapów jest przygotowanie się do śmierci, aby ostateczne spotkanie z Bogiem odbyło się w klimacie wewnętrznego pokoju, przy świadomości, że przyjmuje nas Ten, „który nas utkał w łonie matki” (por. Ps 139 [138], 13b) i który zechciał uczynić nas na „swój obraz i podobieństwo” (por. Rdz 1, 26) ${ }^{94}$.

\section{Włączenie seniorów do aktywności społecznej}

Jedną z dróg do rozwiązania problemów dotyczących starzenia się ludzkości jest włączenie człowieka starszego w aktywne życie społeczne ${ }^{95}$. Seniorów nie należy traktować jako tych, którzy potrzebują wyłącznie pomocy i opieki ${ }^{96}$. Ludzie starsi nie mogą się zamykać „w kącie przymusowej bezczynności" ${ }^{\text {97 }}$. Nie powinni też ulegać pokusie nostalgicznego wspominania przeszłości, która i tak nie wróci, ale winni zaangażować się w teraźniejszość ${ }^{98}$. Nawet jeśli z trudem udaje się im zrozumieć do-

90 Por. Papieska Rada ds. Świeckich, Godność i posłannictwo ludzi starszych $w$ Kościele i w świecie, w: W trosce o życie..., dz. cyt., s. 502, nr 1.

${ }_{91}$ Jan Paweł II, List Do moich braci i sióstr - ludzi w podeszłym wieku, dz. cyt., nr 2.

${ }_{92}$ Jan Paweł II, List Do moich braci i sióstr - ludzi w podeszłym wieku, dz. cyt., nr 12.

93 Por. Jan Paweł II, List Do moich braci i sióstr - ludzi w podeszłym wieku, dz. cyt., nr 10.

94 Por. Jan Paweł II, Bo tu jest twoje życie i długie trwanie twego pobytu na ziemi (Pwt 30, 20), dz. cyt., nr 4.

${ }_{95}$ Por. Jan Paweł II, Ludzie starsi w życiu społeczeństwa..., dz. cyt., s. 8.

96 Por. Jan Paweł II, O szacunku dla ludzi w podeszłym wiek..., dz. cyt., nr 4.

97 Jan Paweł II, Poparcie roli osób starszych $w$ rodzinie i społeczeństwie. Przemówienie..., dz. cyt., s. 614 , nr 3.

98 Jan Paweł II adhort. apost. Christifideles laici, 48. 
konującą się ewolucję społeczeństwa, ważne jest, by patrzyli z ufnością w przyszłośćc 9 .

Jan Paweł II motywuje seniorów do aktywności. Mówił: „Istnieją wielorakie odcinki, które pozostają otwarte, a w które człowiek starszy mógłby się włączyć, przez działalność przystosowaną do wieku i doświadczenia" ${ }^{100}$. Papież z Polski w wielu przemówieniach wzywa do aktywności ludzi starszych na rzecz społeczeństwa i rodziny. „Starsi, którzy osiągnęli już pewną granicę wieku, powinni z jednej strony pozostawić miejsce siłom bardziej świeżym, z drugiej jednak strony, kiedy są oni jeszcze zdolni do dawania, powinni to czynić" ${ }^{101}$. Jan Paweł II podkreślał, że „w procesie podejmowanych dziś koniecznych reform, seniorzy mogą stanowić element wprowadzający równowagę $\mathrm{w}$ życie społeczne, tak aby postęp dokonywał się nie przez burzliwe eksperymenty, lecz w sposób roztropny i stopniowy" ${ }^{102}$.

Nie należy też lekceważyć doświadczenia zdobytego z wiekiem przez seniorów $w^{103}$. Ludzie starsi dzięki swej dojrzałości i doświadczeniu mogą udzielać młodym rad i cennych pouczeń" ${ }^{104}$. Mówi się, że to „żywe biblioteki" mądrości, strażnicy bezcennego dziedzictwa ludzkiego i duchowego ${ }^{105}$. Służą oni dojrzałymi radami, łagodzą namiętności i pomnażają mądrość.

Z mądrości i doświadczenia życiowego dziadków mogą skorzystać najbliżsi. Dotyczy to choćby młodych małżonków. Kiedy przeżywają oni trudności życiowe, to w nich znajdują ludzi godnych zaufania, przed którymi otworzą się i zasięgną rady. Także wnuki, przeżywające z różnych powodów nieobecność rodziców, mogą cieszyć się tak ważną dla nich

99 Por. Jan Paweł II, Cenna rola starszych w Kościele. Przemówienie z 7.09.1994, „L’ Osservatore Romano" wyd. pol. 11 (1994), s. 38, nr 4.

100 Jan Paweł II, Poparcie roli osób starszych $w$ rodzinie i społeczeństwie. Przemówienie..., dz. cyt., s. 614, nr 3; por. P. Morciniec, Starzeć się z godnościa. Od doświadczenia straty do owocowania, „Polonia Sacra” 19 (2015), s. 62-65.

101 Jan Paweł II, Poparcie roli osób starszych $w$ rodzinie i społeczeństwie. Przemówienie..., dz. cyt., s. 614, nr 3.

${ }_{102}$ Jan Paweł II, Środki Przekazu Społecznego i problemy ludzi starszych, Orędzie na XVI Światowy Dzień Środków Przekazu Społecznego, dz. cyt., s. 27, nr 3.

103 Por. Jan Paweł II, O szacunku dla ludzi w podeszłym wieku..., dz. cyt., nr 5.

104 Jan Paweł II, List Do moich braci i sióstr - ludzi w podeszłym wieku, dz. cyt., nr 10.

105 Por. Jan Paweł II, List Do moich braci i sióstr - ludzi w podeszłym wieku, dz. cyt., nr 12. 
pomocą dziadków ${ }^{106}$. Dzięki zgromadzonemu w ciągu wielu lat bogatemu doświadczeniu seniorzy mogą, a nawet powinni dzielić się swoją mądrością, dawać świadectwo nadziei i miłości.

Ludzie starsi pomagają nam mądrzej patrzeć na ziemskie wydarzenia, ponieważ dzięki życiowym doświadczeniom zyskali wiedzę i dojrzałość. Są strażnikami pamięci zbiorowej, a więc mają szczególny tytuł, aby być wyrazicielami wspólnych ideałów i wartości, które są podstawą i regułą życia społecznego. Mogą oni dzięki swej dojrzałości udzielać młodym rad i cennych pouczeń ${ }^{107}$.

Pierwszym środowiskiem, w którym powinni podjąć swoją działalność ludzie starsi, jest rodzina ${ }^{108}$, dla której ich rady i wskazania nadal mogą być cenne. Niezwykle przydatne jest przekazanie przez nich tradycji i zwyczajów rodzinnych czy przekonań religijnych ${ }^{109}$. Dzięki obecności osób w podeszłym wieku wiele może skorzystać również wspólnota chrześcijańska. Chodzi tu zwłaszcza o sferę ewangelizacji. Wiadomo, że liczna grupa wnuków poznaje podstawy wiary dzięki dziadkom ${ }^{110}$. Wiadomo, że ,wiele osób znajduje zrozumienie i wsparcie u ludzi starych, samotnych lub chorych, ale umiejących dodać otuchy przez życzliwą radę, milczącą modlitwę, świadectwo cierpienia znoszonego z wytrwałą ufnością"111.

Troszcząc się o lepsze włączenie seniorów do społeczeństwa, „trzeba dbać o rozwijanie w opinii publicznej świadomości, że ludzie starsi zawsze stanowią wartość, którą należy docenić. Konieczne jest w związku z tym zwiększenie pomocy ekonomicznej oraz inicjatyw ustawodawczych, dzięki którym nie będą oni wyłączeni z życia społecznego"112.

106 Por. Jan Paweł II, Środki Przekazu Społecznego i problemy ludzi starszych, Orędzie na XVI Światowy Dzień Środków Przekazu Społecznego, dz. cyt., s. 27, nr 3.

107 Por. Jan Paweł II, List Do moich braci i sióstr - ludzi w podeszłym wieku, dz. cyt., nr 10; J. Makselon, Psychologiczno-egzystencjalne aspekty starości, w: Starość. Problem czy szansa?..., dz. cyt., s. 164-165.

108 Jan Paweł II, Poparcie roli osób starszych $w$ rodzinie i społeczeństwie. Przemówienie..., dz. cyt., s. 614, nr 4.

109 Por. Jan Paweł II, O szacunku dla ludzi w podeszłym wieku..., dz. cyt., nr 5.

110 Por. Jan Paweł II, List Do moich braci i sióstr - ludzi w podeszłym wieku, dz. cyt., nr 13.

111 Por. Jan Paweł II, List Do moich braci i sióstr - ludzi w podeszłym wieku, dz. cyt., nr 13.

112 Jan Paweł II, Bo tu jest twoje życie i długie trwanie twego pobytu na ziemi (Pwt 30, 20)..., dz. cyt., nr 2. 


\section{Zakończenie}

Starość jest etapem życia. Najogólniej rzecz biorąc, można wobec niej przyjąć postawę akceptacji albo odrzucenia. Nauczanie Kościoła podkreśla szacunek wobec osób starszych. Czerpie on swoje podstawy z Biblii, która w sposób bardzo dostojny wypowiada się na temat starości. W kontekście postępującego procesu starzenia się ludności, zwłaszcza w Europie, konieczne jest przemyślenie na nowo struktury ekonomicznej społeczeństwa i wzajemnych relacji między pokoleniami. W takiej sytuacji nieodzowne jest poparcie kultury akceptującej starość i sprzeciwiającej się tendencjom marginalizacji ludzi w podeszłym wieku.

W celu przeciwdziałania wykluczeniu osób starszych trzeba podkreślać respekt wobec godności osoby ludzkiej, która nie znika w miarę upływu lat i pogarszającego się stanu zdrowia. Należy również zadbać o sprawiedliwy podział dóbr, aby mogli z nich korzystać ludzie starsi. Jest to obowiązek społeczeństwa i państwa. Kościół domaga się, aby nasza cywilizacja zapewniła ludziom starszym wszechstronną opiekę. Zalicza się do niej także wsparcie duszpasterskie.

Aby dobrze przeżyć starość, trzeba się do niej przygotowywać już wcześniej. Istotna jest tutaj aktywność fizyczna i psychiczna. Odpowiedni tryb życia, prawidłowa dieta, wystrzeganie się nałogów - to tylko niektóre czynniki hamujące starzenie się. Duchowość chrześcijańska proponuje rozwój wstrzemięźliwości, która pomaga zachować właściwe proporcje pomiędzy ludzkim „być” i „mieć”. Trzeba wreszcie dodać, że starość jest szansą dalszego rozwoju. Może on mieć miejsce poprzez aktywne włączenie się do życia społecznego. Społeczeństwo winno korzystać z doświadczenia i mądrości seniorów. 


\section{Summary}

\section{Kościół wobec zagrożeń związanych z wykluczeniem przez starość}

Współczesna dyskusja na temat starości koncentruje się wokół pogłębiającego się niżu demograficznego. Ta nowa rzeczywistość staje się wielkim wyzwaniem dla państwa, społeczeństwa, rodziny i Kościoła. Aby zapobiec odsuwaniu osób trzeciego i czwartego wieku na margines, należy respektować osobową godność w starości. Kościół akcentuje w swoim nauczaniu absolutną wartość osoby ludzkiej, i to w każdej bez wyjątku fazie jej istnienia.

Kształtowanie dojrzałych postaw wobec starości jest kluczowym działaniem potrzebnym do eliminowania zachowań prowadzących do marginalizacji i dyskryminacji osób w podeszłym wieku. Każde społeczeństwo jest zobowiązane do szacunku wobec osób starszych. Nieodzowna jest też solidarność między różnymi pokoleniami.

Człowieka starego nie należy traktować wyłącznie jako tego, który potrzebuje pomocy.Jedną z dróg do rozwiązania problemów dotyczących starzenia się ludzkości jest włączenie człowieka starszego w aktywne życie społeczne. Seniorzy nie powinni dobrowolnie wycofywać się z życia społecznego. Ich zadaniem jest wspomaganie środowisk pracy, udzielanie młodym rad, dawanie świadectwa o wartościach humanistycznych, wprowadzanie równowagi w życie społeczne.

Słowa kluczowe: starość, aktywizacja seniorów, wykluczenie, demografia, wsparcie

Kościoła

\section{The Church in the Face of Threats Related to the Marginalization of Older People}

The contemporary discussion on old age focuses on the problem of a still deepening population decline. The prolongation of the average life span and a distinct decrease in the birth rate have caused that the number of the old is still growing and the number of the young is diminishing. The new tendency is becoming a great challenge for the state, society, family and the Church. Until societies which relegate the elderly to the fringes as unproductive people in her teaching, the Church accentuates the absolute value of the human person in each stage of life.

The formation of a mature approach towards old age is the key to eliminating such behaviours which lead to the marginalization and discrimination of the elderly. Each society is obliged to respect its older people. Also solidarity between different generations is indispensable. We should not old people as ones needing help only. One of the ways of solving the issues of ageing is to include old people in active social life. Seniors should not withdraw from social life voluntary. Their task is supporting 
work environments, giving advice to the young, being a witness of humanistic values, and introducing balance in social life.

Keywords: old age, activation of seniors, exclusion, demography, support of the Church

\section{Bibliografia}

Arystoteles, Ethica Nicomachea IX 1,1165a 28-30, w: Arystoteles, Etyka Nikomachejska, tłum. D Gromska, Warszawa 1956 (Biblioteka Klasyków Filozofii 25), za: R. Majeran, Arystoteles o starości, „Vox Patrum” 31 (2011) 56, s. 105-118.

Benedykt XVI, Dziadkowie sa cennym skarbem każdej rodziny. Przemówienie do uczestników XVIII Zgromadzenia Plenarnego Papieskiej Rady ds. Rodziny, 5 kwietnia 2008, s. 1 http://www.opoka.org.pl/biblioteka/W/WP/benedykt_xvi/przemowienia/dziadkowie_05042008.html (18.06.2018).

Benedykt XVI, Przemówienie w Domu dla osób starszych, Londyn, 18 września 2010 https://www.deon.pl/religia/kosciol-i-swiat/z-zycia-kosciola/art,3092,benedykt-xvi-w-domu-dla-osob-starszych.htlm (18.06.2018).

Bréhant J., Thanatos: Chory i lekarz w obliczu śmierci, przeł. U. Sudolska, Warszawa 1993.

Czerniawska O., Starość wczoraj, dziś i jutro, http://kutw.kk.jgora.pl/witryna 3/starosc.htm (18.06.2018).

Sobór Watykański II, Dekret o apostolstwie świeckich, w: Sobór Watykański II, Konstytucje, dekrety, deklaracje, Poznań 1968, s. 379-405.

Dziedzic J., Kościót wobec kwestii ekologicznej, w: Ekoturystyka, red. J. Dziedzic, P. Tirpak, Presov 2013, s. 36-52.

Dziedzic J., Kościół wobec starości. Perspektywa pastoralnoteologiczna, w: Starość. Problem czy szansa? Refleksja pastoralnoteologiczna, red. J. Dziedzic, Kraków 2015, s. $45-75$.

Dziedzic J., Nauczanie Jana Pawła II o szacunku dla osób wykluczonych przez starość, w: De revolutionibus orbium populorum Joannis Pauli II. Papież wobec wykluczenia społecznego, red. K. Pilarczyk, Warszawa 2015, s. 477-502.

Dziedzic J., Spór o eutanazję, Kraków 2005.

Dziedzic J., Wsparcie osób starszych. Przeszkody i szanse w poszukiwaniu godnej starości, w: Odnaleźć wykluczonych, red. J. Dziedzic, J. Klimek, Kraków 2014, s. 213-230.

Dzięgielewska M., Aktywność społeczna i edukacja w fazie starości, w: Podstawy gerontologii społecznej, red. B. Szatur-Jaworska, Warszawa 2006, s. 160-164.

Dzięgielewska M., Wolontariat ludzi starszych, w: Starzenie się a satysfakcja życia, red. S. Steuden, M. Marczuk, Lublin 2006, s. 261-271.

Eibach U., Sterbehilfe-Ttong aufverlangen? Eine theologisch-ethische Stellungnahme zur Frage der Euthanasie, Bonn 1987.

Franciszek, Adhortacja apostolska Evangelii gaudium.

Franciszek, Bronić się przed objawami psychicznej starości. Homilia z dnia 26 lipca 2013 http://teologia.pl/franciszek/franciszek_starosc_jak_wino.htm (18.06.2018). 
Franciszek, Encyklika Laudato si'.

Franciszek, Adhortacja apostolska Gaudate et Exultate.

Franciszek, Potrzebujemy osób starszych, które się modlą. Przemówienie z 11 marca 2015 https://papiez.wiara.pl/doc/2387276.Potrzebujemy-osob-starszych-ktore-siemodla (15.07.2018).

Franciszek, Starsi to ofiary kultury odrzucenia, Przemówienie w Małym Domu Opatrzności Bożej, Turyn, 21 czerwca 2015, https://papiez.wiara.pl/doc/2555377.Starsi-to-ofiarykultury-odrzucenia/2 (15.07.2018).

Grzanka-Tykwińska A., Chudzińska M., Podhorecka M., Kędziora-Kornatowska K., Uniwersytety Trzeciego Wieku wczoraj, dziś i jutro, „Gerontologia Polska” 4 (2015), s. 165-168.

Gwóźdź W., Eutanazja jako problem moralny, „Studia Sandomierskie” 2 (1981) s. 458. Irek W., Koniec czy początek? Szkice o godnym starzeniu się i umieraniu, Wrocław 2009. Jan Paweł II, Adhortacja apostolska Christifideles laici.

Jan Paweł II, Bo tu jest twoje życie i długie trwanie twego pobytu na ziemi (Pwt 30, 20). Orędzie Ojca Świętego Jana Pawła II na Wielki Post 2005 roku, Watykan, 8 września 2004.

Jan Paweł II, Cenna rola starszych w Kościele. Przemówienie z 7.09.1994, „L' Osservatore Romano" wyd. pol. 11 (1994), s. 38.

Jan Paweł II, Adhortacja apostolska Familiaris consortio.

Jan Paweł II, List Ojca Świętego Do moich braci i sióstr - ludzi w podeszłym wieku.

Jan Paweł II, Ludzie starsi $w$ życiu społeczeństwa. List papieski do uczestników II Światowego Zgromadzenia poświęconego problemom starzenia się ludności, 03.04.2002, https://opoka.org.pl/biblioteka/W/WP/jan_pawel_ii/listy/ludzie_starsi_03042002.html (15.07.2018).

Jan Paweł II, Nadzieja nadaje cierpieniu nowy sens. Orędzie na VI Światowy Dzień Chorego 11.02.1998, „L'Osservatore Romano” wyd. pol., 10 (1997), s. 4-6.

Jan Paweł II, O szacunku dla ludzi w podeszłym wieku. Przemówienie Ojca Świętego do uczestników konferencji zorganizowanej przez Papieską Radę ds. Duszpasterstwa Stużby Zdrowia, Watykan 31.10. 1999, w: W trosce o życie. Wybrane dokumenty Stolicy Apostolskiej, t. 2, red. J. Brusiło, Tarnów, 2012, s. 240-243.

Jan Paweł II, Poparcie roli osób starszych $w$ rodzinie i społeczeństwie. Przemówienie do członków Krajowej Federacji Handlu i Turystyki, Watykan 29.04.1982, w: Nauczanie Papieskie, t. 5/1, Poznań 1993, s. 612-616.

Jan Paweł II, O cierpieniu. Wypowiedzi Ojca Świętego do chorych i pracowników służby zdrowia (1982-1984), t. 2, Niepokalanów 1988.

Jan Paweł II, Towarzyszyć choremu aż do końca. Przemówienie do uczestników konferencji Papieskiej Rady ds. Duszpasterstwa Służby Zdrowia 12 listopada 2004, https:// opoka.org.pl/biblioteka/W/WP/jan_pawel_ii/przemowienia/sl_zdrowia_12112004. html (20.05.2018).

Kudasiewicz J., Sens starości w świetle Pisma Świętego, w: Ludzie chorzy i starsi w Kościele, red. B. Dąbrowski, Warszawa 1981, s. 91-101.

Leonowicz J., Duszpasterstwo ludzi starych, w: Duszpasterstwo specjalistyczne, red. R. Kamiński, B. Drożdż, Lublin 1998, s. 39-54. 
Majkrzak H., Starość człowieka jako problem filozoficzny w myśli klasycznej, „Człowiek w Kulturze" 14 (2002), s. 199-209.

Makselon J., Psychologiczno-egzystencjalne aspekty starości, w: Starość. Problem czy szansa? Refleksja pastoralnoteologiczna, red. J. Dziedzic, Kraków 2015, s. 155-171.

Marczewski K. M., Z upływem lat oswajamy się z myśla o zmierzchu (Duszpasterstwo ludzi starszych), „Roczniki Naukowe Caritas” 10 (2006), s. 28-35.

Morciniec P., Starzeć się z godnością. Od doświadczenia straty do owocowania, „Polonia Sacra" 19 (2015), s. 62-65.

Papieska Rada ds. Świeckich, Godność $i$ posłannictwo ludzi starszych w Kościele $i$ w świecie, w: W trosce o życie. Wybrane dokumenty Stolicy Apostolskiej, t. 2, red. J. Brusiło, Tarnów 2012, nr 1, s. 499-516.

Paweł VI, Encyklika Humanae vitae.

Platon, Prawa, III, 690, tłum. M. Maykowska, Warszawa 1960.

Przygoda W., Wezwania duszpasterskie wobec osób w podeszłym wieku, w: Starość. Problem czy szansa? Refleksja pastoralnoteologiczna, red. J. Dziedzic, Kraków 2015, s. 77-116.

Rembowski R., Psychologiczne problemy starzenia się człowieka, Warszawa-Poznań 1984.

Romaniuk K., Lata podeszłe i starość według Biblii, Warszawa 1993.

Siemianowski A., Starość w perspektywie ostatecznej, „Ethos” 3 (1999), s. 104-105.

Sławiński H., Przepowiadanie do ludzi w podeszłym wieku, „Analecta Cracoviensia” 48 (2016), s. 141-161.

Stańczak J., Szałtys D., Witkowski J., Potencjał ludnościowy Unii Europejskiej, w: Ekonomiczna pozycja Europy w świecie, red. J. Kleer, K. Prandecki, Warszawa 2016, s. $17-20$.

Uzar K., Wychowanie w perspektywie starości. Personalistyczne podstawy geragogiki, Lublin 2011.

Sztuka J., Formacja do starości, „Ateneum Kapłańskie” 157 (2011), z. 1, s. 46-51.

Winiarski R., Zdebski J., Psychologia turystyki, Warszawa 2008.

Wyrostkiewicz W., Ekologia ludzka. Osoba i jej środowisko z perspektywy teologicznomoralnej, Lublin 2007.

Wyrwicka K., Osoby starsze w systemie pomocy społecznej, „Praca Socjalna”. - 2003, nr 2, s. 109.

Zieliński K., Edukacyjne walory sportu rekreacyjnego i wyczynowego. Perspektywa personalistyczna, w: Edukacja sportu, red. Z. Dziubiński, Warszawa 2004, s. 147-150.

Zych A., Starość - starzenie się, w: Encyklopedia pedagogiczna XXI wieku, t. 5, red. T. Pilch, Warszawa 2005, s. 949-950. 